\title{
Nerve Growth Factor Induces Process Formation in Meningeal Cells: Implications for Scar Formation in the Injured CNS
}

\author{
Jonas Frisén, ${ }^{1}$ Mårten Risling, ${ }^{2}$ Laura Korhonen, ${ }^{3}$ Ute Zirrgiebel, ${ }^{4}$ Clas B. Johansson, ${ }^{1,2}$ Staffan Cullheim, ${ }^{2}$ \\ and Dan Lindholm ${ }^{3}$ \\ ${ }^{1}$ Department of Cell and Molecular Biology, Medical Nobel Institute, and 2Department of Neuroscience, Karolinska \\ Institute, S-171 77 Stockholm, Sweden, 'Department of Developmental Neuroscience, Biomedical Center, S-751 23 \\ Uppsala, Sweden, and ${ }^{4}$ Brain Tumor Research Centre, Montreal Neurological Institute, Montreal, PQ, Canada, H3A 2B4
}

Nerve growth factor (NGF) induces the differentiation and supports the survival of subpopulations of neurons in the PNS and CNS. Here we report that meningeal cells in the pia mater express immunoreactivity and mRNA for both known NGF receptors, the low-affinity receptor p75 and the tyrosine kinase receptor trkA. NGF induces rapid tyrosine phosphorylation of trkA in meningeal cells in vitro. NGF does not stimulate proliferation of primary meningeal cells but induces process out- growth. p75- and trkA-immunoreactive meningeal cells with long processes, resembling NGF-treated cells in vitro, are abundant in the scar tissue that forms at spinal cord lesions in rat and cat. These data suggest that NGF, which is expressed at increased levels in the brain and spinal cord after lesions, may be involved in scar formation in the injured CNS.

Key words: NGF; trkA; p75; injury; regeneration; meningeal cells
Nerve growth factor (NGF) is required for the survival of sympathetic neurons and some sensory neurons in the peripheral nervous system during development (Levi-Montalcini, 1987; Crowley et al., 1994; Smeyne et al., 1994). In the CNS, NGF regulates the phenotype of septal cholinergic neurons (Thoenen, 1991; Sofroniew et al., 1993). p75, also known as the low-affinity neurotrophin receptor, was the first identified NGF-binding molecule that has a relative molecular mass of $75 \mathrm{kDa}$ (Johnson et al., 1986; Radeke et al., 1987) and in addition to NGF, binds the structurally and functionally related neurotrophic factors in the neurotrophin family (Ernfors et al., 1990; Rodriguez-Tébar et al., 1990, 1992; Hallböök et al., 1991; Squinto et al., 1991). trkA is a signal-transducing tyrosine kinase receptor for NGF (Kaplan et al., 1991; Klein et al., 1991; Barbacid, 1995). NGF can induce responses in fibroblasts expressing trkA in the absence of p75 (Cordon-Cardo et al., 1991), and mutant NGF molecules that do not bind p75 can still induce effects in neuronal cells in vitro (Ibáñez et al., 1992). The role of p75 has been difficult to establish, but some data suggest that p75 may increase the neuronal sensitivity to NGF (Davies et al., 1993; Barker and Shooter, 1994; Lee et al., 1994; Maliartchouk and Saragovi, 1997; Rydén et al., 1997). There are also reports that p75 may affect the signal transduction pathways for NGF (Hantzopoulos et al., 1994; Verdi et al., 1994). Furthermore, there is increasing evidence that p75 may induce cell death during NGF binding in cells that do not express trkA (Dechant and Barde, 1997).

Received March 25, 1998; revised May 13, 1998; accepted May 13, 1998.

This study was supported by grants from the Swedish Medical Research Council, the Swedish Medical Society, Stiftelsen Sigurd och Elsa Goljes minne, Stiftelsen Lars Hiertas Minne, Jeanssons stiftelse, Ostermans stiftelse, Magnus Bergvalls stiftelse, Tore Nilssons stiftelse, the Wenner-Gren Center Foundations, Björklunds fond, Marcus Borgströms stiftelse, Åke Wibergs stiftelse, Schweizer Paraplegiker Stiftung (SPS), and Kapten Arthur Erikssons fond. We gratefully acknowledge Ms. M. Meier and Mr. J. Richter for expert technical assistance. We thank Dr. David Kaplan for kindly providing trk antiserum.

Correspondence should be addressed to Dr. Jonas Frisén, Department of Cell and Molecular Biology, Karolinska Institute, S-171 77 Stockholm, Sweden.

Copyright (C) 1998 Society for Neuroscience $0270-6474 / 98 / 185714-09 \$ 05.00 / 0$
In contrast to the restricted expression of trkA, the structurally and functionally related neurotrophin receptors trkB and trkC are more widespread in neurons in the PNS and CNS (Merlio et al., 1992). The trkB and trkC loci encode, in addition to fulllength tyrosine kinase receptors, truncated receptors lacking the signal transducing domain that are expressed at high levels by glial cells (Klein et al., 1990; Middlemas et al., 1991; Tsoulfas et al., 1993; Valenzuela et al., 1993). The function of glial trkB and trkC receptors is poorly understood, although developmental regulation and altered expression by injury may indicate important functions (Frisén et al., 1992, 1993; Funakoshi et al., 1993). After brain and spinal cord injuries, astrocytes express truncated trkB-receptors at highly elevated levels (Frisén et al., 1992, 1993; Beck et al., 1993). Additionally, both trkB and p75 are expressed at high levels by meningeal cells invading the injured CNS (Risling et al., 1992; Frisén et al., 1992).

We here report that leptomeningeal cells in the pia mater coexpress p75 and trkA, and that NGF induces rapid phosphorylation of trkA on tyrosine residues in these cells in vitro. NGF is not mitogenic for leptomeningeal cells but stimulates process outgrowth in vitro. In the injured rat and cat spinal cord, trkAand p75-immunoreactive leptomeningeal cells with long processes are abundant in the scar tissue formed at the lesion, implicating NGF in CNS scar formation.

\section{MATERIALS AND METHODS}

Animals and surgery. Adult female Sprague Dawley rats (200 gm) were anesthetized with chloral hydrate $(300 \mathrm{mg} / \mathrm{kg})$, and adult cats were anesthetized with pentobarbitone sodium $(30 \mathrm{mg} / \mathrm{kg})$ and xylazine chloride $(0.4 \mathrm{mg} / \mathrm{kg})$. A longitudinal incision was made in the left ventral funiculus of the L5 (rats, $n=10$ ) or L7 (cats, $n=6$ ) segment as described (Risling et al., 1983), resulting in intramedullary axotomy of motoneurons. In other rats $(n=5)$ an incision was made in the lateral funiculus in the L4/L5 segment. The rats were allowed to survive for $7 \mathrm{~d}(n=8)$ or 3 weeks $(n=7)$, and the cats were allowed to survive for $4 \mathrm{~d}(n=1)$, $10 \mathrm{~d}(n=2), 3$ weeks $(n=2)$, or 2 months $(n=1)$. The use of animals for this study was approved by the Swedish ethical committee.

Immunofluorescence histochemistry. Anesthetized animals were per- 

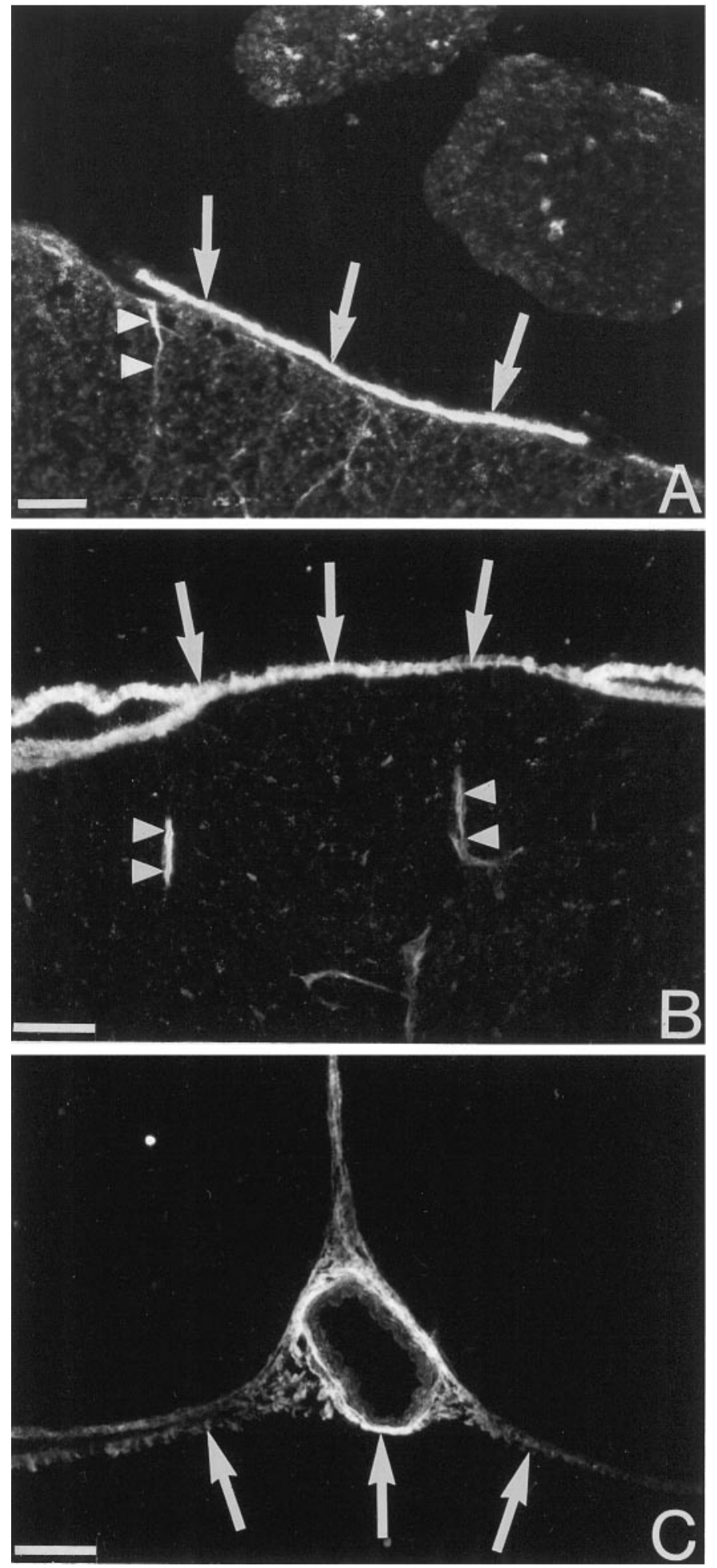

Figure 1. trkA-like immunoreactivity in the pia mater. The micrographs show immunohistochemical detection of trkA at the surface of the uninjured adult cat $(A)$ and rat $(B, C)$ lumbar spinal cord. The arrows indicate labeling in the pia mater. Thin cell process associated with blood vessels extend into the spinal cord (arrowheads). In $C$, trkA-LI is seen in the pia mater in the ventral fissure and in the pia mater surrounding a blood vessel. Scale bars, $50 \mu \mathrm{m}$.

fused through the ascending aorta with Tyrode's solution followed by $4 \%$ formaldehyde with $0.4 \%$ picric acid in 300 mOsm phosphate buffer. Tissues were rapidly dissected out and post-fixed in the fixative for 90

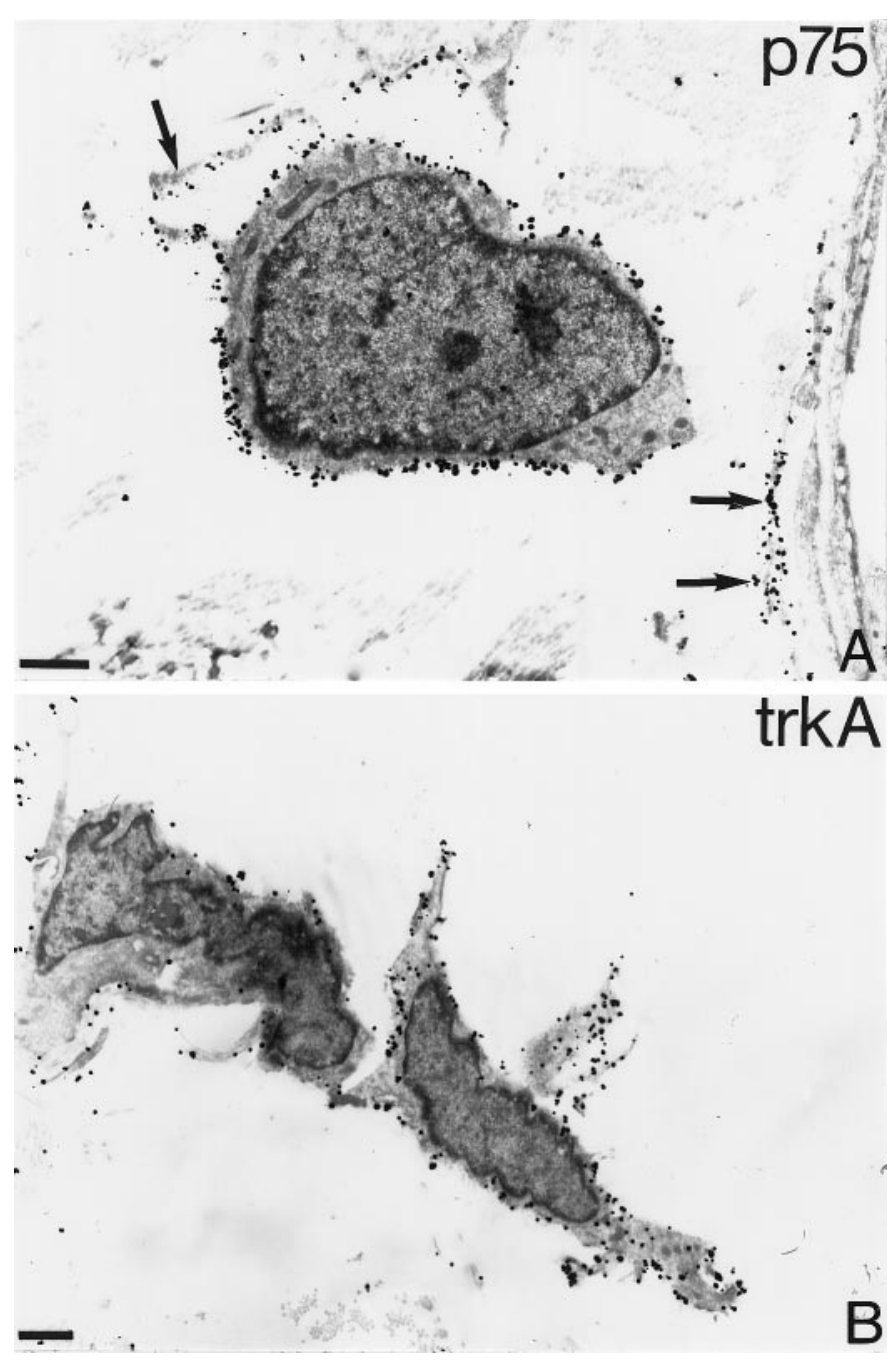

Figure 2. Ultrastructural localization of p75- and trkA-like immunoreactivity. Silver-enhanced immunogold electron microscopy of pia mater covering the uninjured spinal cord is shown. Leptomeningeal cells with long processes (arrows in $A$ ) show strong p75-LI $(A)$ and trkA-LI $(B)$ at the cell surface. Scale bars, $1 \mu \mathrm{m}$.

min, and subsequently rinsed overnight in 300 mOsm phosphate buffer with $10 \%$ sucrose. Sections $(14 \mu \mathrm{m})$ were cut on a cryostat, thawed onto chrome alum-coated object slides, and incubated in a humid atmosphere at $4^{\circ} \mathrm{C}$ for $18-24 \mathrm{hr}$ with rabbit anti-trkA antiserum (trk763, diluted 1:100, Santa Cruz Biotechnology, Santa Cruz, CA; or OA-11-790A, diluted 1:200, Cambridge Research Biochemicals). Other sections were incubated with mouse monoclonal antibodies against p75 (diluted 1:100) (Ross et al., 1984). The sections were then rinsed in 0.01 м PBS, pH 7.4, and incubated for $45 \mathrm{~min}$ at $20^{\circ} \mathrm{C}$ with rhodamine-conjugated or fluorescein isothiocyanate (FITC)-conjugated swine anti-rabbit antiserum (diluted 1:10; Dako, Glostrup, Denmark), Cy3-conjugated affiniPure donkey anti-rabbit $\operatorname{IgG}$ (diluted 1:500; Jackson ImmunoResearch Laboratories, West Grove, PA), or rhodamine-conjugated goat antimouse antiserum (diluted 1:100; Boehringer Mannheim, Mannheim, Germany). All antisera were diluted in $0.01 \mathrm{M}$ PBS containing $0.3 \%$ Triton X-100, $0.5 \%$ bovine serum albumin (BSA), and $0.1 \%$ sodium azide. After the sections were rinsed in PBS, they were mounted in a mixture of glycerol and PBS (1:9) and coverslipped. The specificity of the antibody labeling was tested by incubation with the secondary antibody in the absence of primary antibody. In other sections, the trk763 antiserum was preincubated with the peptide $(20 \times$ excess) against which the antisera were raised. All specific labeling was abolished in both of these control experiments.

Immunoelectron microscopy. Anesthetized cats were perfused as described above, with the exception that $0.1 \%$ glutaraldehyde was used 


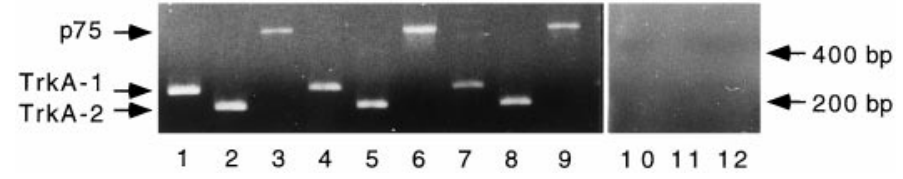

Figure 3. 3 RT-PCR detection of $\mathrm{p} 75$ and trkA mRNA. mRNA was extracted from PC12 cells (lanes 1-3), septum (lanes 4-6), and pia mater (lanes 7-9) and subjected to RT-PCR amplification with primers for $\mathrm{p} 75$ and two different sets of primers for trkA. No amplification from pia mater mRNA was seen in the absence of reverse transcriptase (lanes $10-12)$.

instead of picric acid in the fixative. Spinal cords were cut in $60-\mu \mathrm{m}$-thick sections on a cryostat. The sections were treated in sodium borohydride, transferred through graded steps of ethanol, and then rehydrated (Priestley, 1984). The sections were then incubated for 18-24 hr with rabbit anti-trkA antiserum and/or mouse monoclonal antibodies to human p75 as above. After they were rinsed, the sections were incubated with $0.8 \mathrm{~nm}$ gold particle-conjugated goat anti-rabbit antiserum (diluted 1:50; Aurion) or $1 \mathrm{~nm}$ goat anti-mouse antiserum (diluted 1:50; Auroprobe One, Amersham, Arlington Heights, IL). In double-labeled sections, the gold particle-conjugated goat anti-rabbit antiserum was combined with biotinconjugated goat anti-mouse antiserum (diluted 1:200; Vector Laboratories, Burlingame, CA) for $2 \mathrm{hr}$ at $20^{\circ} \mathrm{C}$. All antisera were diluted in 0.01 M PBS containing 0.5\% gelatin (Janssen Biochimica, Berse, Belgium). The sections were osmicated for $30 \mathrm{~min}$, and gold labeling was intensified with a silver enhancement reaction (Intense M, Amersham). Biotinconjugated antibodies were visualized by adding avidin-conjugated horseradish peroxidase (Vector) and processing with DAB as chromogen. The sections were then dehydrated in graded steps of acetone and embedded in Vestopal W between transparent acetate foils. Selected areas were thin-sectioned by the use of an Ultratome III (LKB) and contrasted with uranyl acetate and lead citrate. Pieces of pia mater stripped from cervical spinal cord were processed exactly as the spinal cord sections. A Philips CM12 electron microscope was used. No specific labeling was seen when the primary antibody was omitted.

Cell cultures. The leptomeninges were carefully removed from the convexities of the cerebral hemispheres of newborn rats and enzymatically digested with papain (Sigma, St. Louis, MO) $(2.5 \mathrm{mg}$ in $5 \mathrm{ml}$ of PBS containing $1 \mathrm{mg} / \mathrm{ml} \mathrm{BSA}, 10 \mathrm{~mm}$ glucose, and $100 \mu \mathrm{g} / \mathrm{ml}$ DNase I) for 30 min at $37^{\circ} \mathrm{C}$. The cells were triturated, collected by centrifugation, and resuspended in cell culture medium. Cells were maintained in DMEM (Life Technologies, Gaithersburg, MD) containing 10\% fetal calf serum (Life Technologies), $100 \mathrm{U} / \mathrm{ml}$ penicillin, and $100 \mu \mathrm{g} / \mathrm{ml}$ streptomycin. The medium was changed the next day and thereafter every fourth day. Cell cultures used for immunohistochemistry were fixed for $10 \mathrm{~min}$ with $4 \%$ formaldehyde in PBS and processed as above. Mouse monoclonal antibodies against p75 (Chandler et al., 1984) (final concentration 1.5 $\mu \mathrm{g} / \mathrm{ml}$ ) and trkA (described above) were used. The secondary FITCconjugated anti-mouse antibody was from Sigma, and the Cy3conjugated anti-rabbit antibody was from Jackson ImmunoResearch Laboratories. NGF was prepared from male mouse submandibular glands, and recombinant brain-derived neurotrophic factor (BDNF) was produced using vaccinia virus-infected cultured kidney cells (Götz et al., 1992). Bovine basic fibroblast growth factor (bFGF) was purchased from Boehringer Mannheim.

RT-PCR and Northern blot. Total RNA was extracted by the acid guanidine isothiocyanate/phenol-chloroform method of Chomczynski and Sacchi (1987). The recovery of RNA was measured spectrophotometrically. Reverse transcription was performed using oligo-dT and the avian myeloblastosis virus reverse transcriptase (Life Sciences, Hialeah, FL). For the subsequent PCR reaction for trkA, the following primers were used: sense primer (5'-GCTGGTATGGTGTACCTAGCC-3') corresponding to nucleotides $1914-1935$ in the rat trkA sequence, and one of the two antisense primers A1 (5'-CAGCACCACCCGAAGCTCC-3') or A2 (5'-GCGGTAGAGGATGCTCTCTGG-3') corresponding to nucleotides 2140-2160 and 2084-2105, respectively. The sizes of the amplified products of trkA were $246 \mathrm{bp}$ for trkA-A1 and $191 \mathrm{bp}$ for trkA-A2. The following primers were used to amplify p75: sense (5'-TTCAAGA GGTGGAACAG-3') and antisense (5'-GGGGTCACACTTGAGTG$3^{\prime}$ ) corresponding to nucleotides $816-834$ and 1266-1283 in the rat p75 sequence, resulting in a $476 \mathrm{bp}$ band. GAPDH primers, sense (5'GGACTCCTCAGCAACTGAGGG-3') and antisense (5'-GGCTGTG

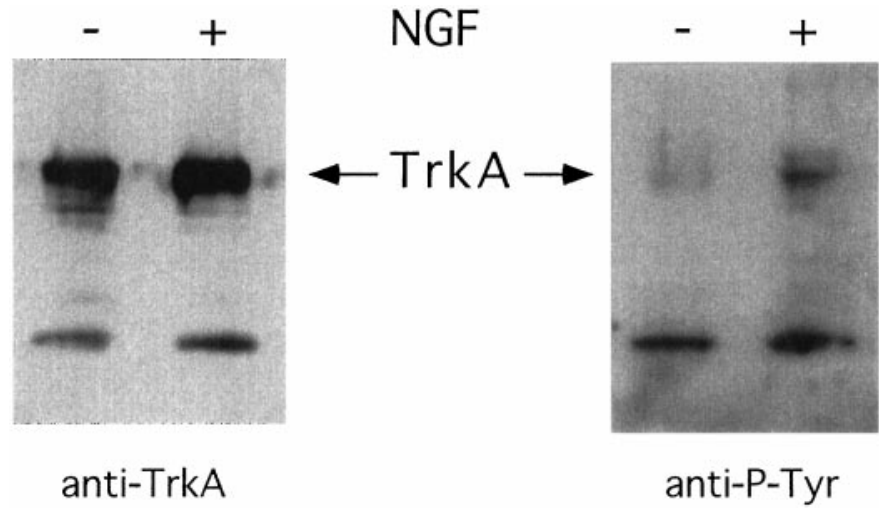

Figure 4. Activation of trkA by NGF in leptomeningeal cells. The cells were lysed, immunoprecipitated with trk-antiserum, separated on SDSPAGE, transferred to a membrane, and incubated with trkA (left panel) or phosphotyrosine (right panel) antibodies. Cells were grown in the absence of NGF (-) or in the presence of NGF for 5 min before lysis (+).

GGCAAGGTCATCCC-3'), were used to estimate that equal amounts of cDNA were used for the assay. PCR reactions were performed in a thermocycler (Perkin-Elmer, Emeryville, CA) passing 35 cycles $(1 \mathrm{~min}$ $94^{\circ} \mathrm{C}, 1 \mathrm{~min} 53^{\circ} \mathrm{C}$, and $2 \min 72^{\circ} \mathrm{C}$ ) using Taq-Polymerase (Perkin-Elmer) in the delivered buffer plus 4\% DMSO. PCR products were separated on Agarose gels (3\% NuSieve Agarose; FMC Bio Products, Rockland, ME) and blotted onto nitrocellulose membranes (Hybond $\mathrm{N}+$, Amersham). The amplified bands were cut out of the gel, cloned into pBluescript, and sequenced using the dideoxy method to verify the molecular identity. No amplification was seen in samples processed without reverse transcriptase.

Immunoprecipitation and Western blotting. Meningeal cells were cultured for $10 \mathrm{~d}$ in $3.5 \mathrm{~cm}$ Petri dishes. Cells were stimulated for $5 \mathrm{~min}$ with $50 \mathrm{ng} / \mathrm{ml}$ NGF followed by cell lysis in $500 \mu$ l lysis buffer (50 mM HEPES, $\mathrm{pH} 7.5,150 \mathrm{~mm} \mathrm{NaCl}, 10 \%$ glycerol, $1 \%$ Triton X-100, $1.5 \mathrm{~mm} \mathrm{MgCl}_{2}, 10$ mM EDTA, $10 \mathrm{~mm}$ sodium pyrophosphate, $1 \mathrm{~mm}$ sodium orthovanadate, $10 \mathrm{~mm} \mathrm{NaF}, 250 \mu \mathrm{M}$ p-nitrophenol phosphate, $10 \mu \mathrm{g} / \mathrm{ml}$ aprotinin, 10 $\mu \mathrm{g} / \mathrm{ml}$ leupeptin, and $1 \mathrm{~mm}$ phenylmethylsulfonyl fluoride). Lysates were centrifuged, and the supernatants were used for immunoprecipitation with anti-pan Trk 203 antibody (Verdi et al., 1994) as described by Moran et al. (1991). The Sepharose A (Pharmacia, Uppsala, Sweden)-bound immunoprecipitates were washed, run on $6 \%$ SDS-PAGE, and transferred to Immobilon-P membranes (Millipore, Bedford, MA), which were incubated with mouse monoclonal anti-phosphotyrosine antibodies (P469; Santa Cruz Biotechnology) or rabbit anti-trkA antibodies (trk763, Santa Cruz Biotechnology). Detection was performed with enhanced chemiluminescence substrate solution (Amersham) after incubation with horseradish peroxidase-conjugated anti-mouse antiserum (Dako).

Cell proliferation assay. The mitogenic activity of NGF, BDNF (50 $\mathrm{ng} / \mathrm{ml})$, and bFGF (10 $\mathrm{ng} / \mathrm{ml})$ was determined by incubating leptomeningeal cells with the respective factor for $2 \mathrm{~d}$. No factor was added to control cultures. During the last $6 \mathrm{hr}$ of incubation, ${ }^{3}[\mathrm{H}]$ thymidine $(2$ $\mu \mathrm{Ci} / \mathrm{ml}$ ) was present, and the amount of TCA-insoluble radioactivity in the cells was subsequently determined.

\section{RESULTS}

\section{Meningeal cells express p75 and trkA}

Two different antisera were used to analyze the expression of trkA-like immunoreactivity (LI). Both antisera gave the same labeling pattern in all analyzed regions of the nervous system (data not shown), which corresponded to that observed in previous trkA localization studies (Verge et al., 1992). No specific labeling was seen in sections incubated with the secondary antiserum in the absence of primary antiserum or in sections incubated with trkA antiserum preincubated with the peptide against which the antiserum was raised (data not shown and see Fig. 9). Except for trkA-LI in thin nerve fibers in the dorsal horn, no labeling of neurons or glial cells was seen within the spinal cord 


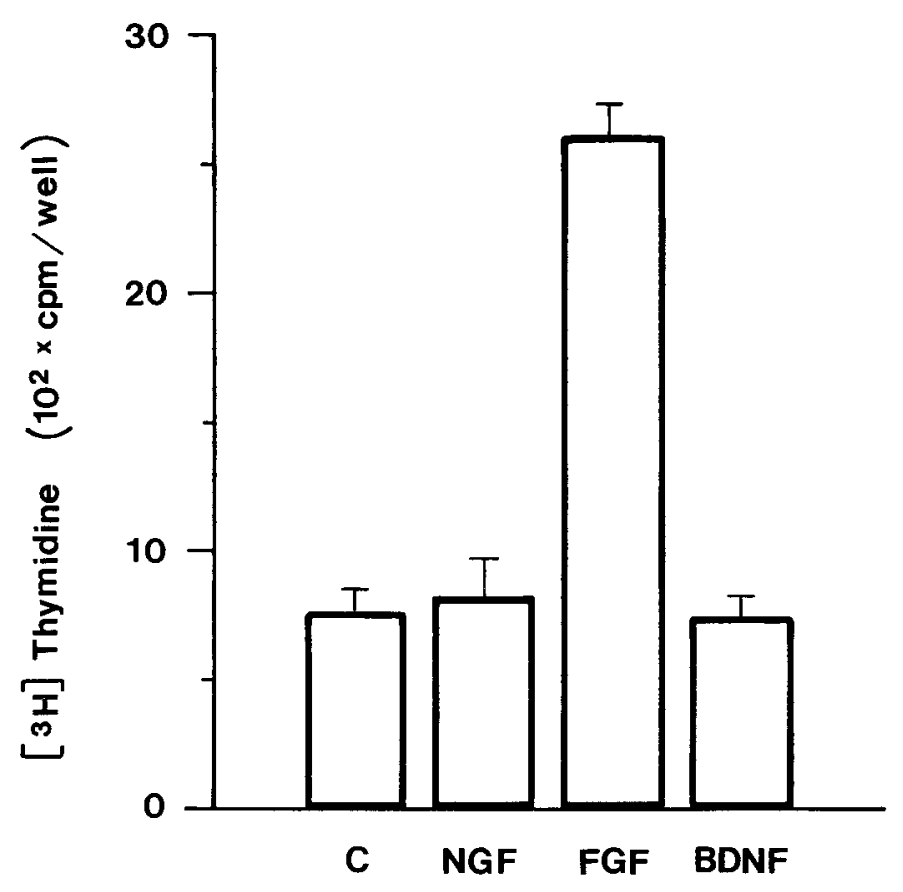

Figure 5. NGF does not stimulate proliferation of leptomeningeal cells. Leptomeningeal cells were cultured in the presence of NGF $(50 \mathrm{ng} / \mathrm{ml})$, bFGF $(10 \mathrm{ng} / \mathrm{ml})$, or BDNF $(50 \mathrm{ng} / \mathrm{ml})$ for $2 \mathrm{~d} .{ }^{3}[\mathrm{H}]$ thymidine was added to the medium for the last $6 \mathrm{hr}$, and incorporation was analyzed. Error bars represent the mean + SD from four independent experiments.

(data not shown). Strong trkA-LI was seen in the pia mater covering the spinal cord (Fig. 1). Thin cell processes extending from the pia mater into the superficial spinal cord, in most cases in association with blood vessels, showed trkA-LI (Fig. 1). Silverenhanced immunogold electron microscopy was used to study p75- and trkA-immunoreactive structures in meninges stripped from the spinal cord at the ultrastructural level. Cells with morphological characteristics of leptomeningeal cells (Peters et al., 1976; Risling et al., 1992) showed strong p75-LI and trkA-LI localized to the cell membrane (Fig. 2). p75-LI was also seen in Schwann cells associated with axons in the meninges (data not shown).

To confirm the immunohistochemical results we analyzed p75 and trkA mRNA expression. RT-PCR demonstrated p75 and
trkA mRNA expression in cultured leptomeningeal cells, as well as in septum and PC12 cells (Fig. 3).

\section{NGF induces tyrosine phosphorylation of trkA in leptomeningeal cells}

NGF binding to trkA receptors induces receptor dimerization and transphosphorylation, initiating the signal transduction by trkA (Kaplan et al., 1991; Klein et al., 1991; Jing et al., 1992). Cultured leptomeningeal cells were lysed, and the lysates were immunoprecipitated with anti-trk antiserum. Western blots were then made, and activated trkA was detected using antiphosphotyrosine antibodies. There was a low degree of phosphorylation of trkA in untreated cultures (Fig. 4). When NGF (50 $\mathrm{ng} / \mathrm{ml}$ ) was added to the cultures, an increase of trkA phosphorylation was seen within 5 min (Fig. 4).

\section{NGF is not mitogenic for leptomeningeal cells}

Previous studies have demonstrated that NGF stimulates proliferation of NIH3T3 cells ectopically expressing trkA (CordonCardo et al., 1991). This prompted us to test wether NGF may be mitogenic for leptomeningeal cells. To this end, we studied ${ }^{3}[\mathrm{H}]$ thymidine and bromodeoxyuridine (BrdU) incorporation in leptomeningeal cells grown in the presence or absence of various factors. As shown in Figure 5, bFGF strongly stimulated proliferation of leptomeningeal cells. In contrast, no change in thymidine incorporation was detected in NGF- or BDNF-treated cells compared with controls (Fig. 5). No difference in the number of labeled nuclei could be detected after BrdU incorporation between NGF-treated leptomeningeal cells and controls (data not shown).

\section{NGF induces process formation in leptomeningeal cells}

Leptomeningeal cells grown in medium supplemented with $10 \%$ fetal calf serum had a flat polyhedral shape. Leptomeningeal cells could easily be distinguished from rare contaminating astrocytes by their coexpression of p75-LI and trkA-LI (Fig. 6) and their lack of glial fibrillary acidic protein-LI. Schwann cells, which also express p75 but not trkA, did not proliferate in these cultures. After the cells had been grown in the presence of NGF for $3 \mathrm{~d}$, the morphology of the leptomeningeal cell was drastically changed: long thin processes extended from the cell bodies (Fig. 7).

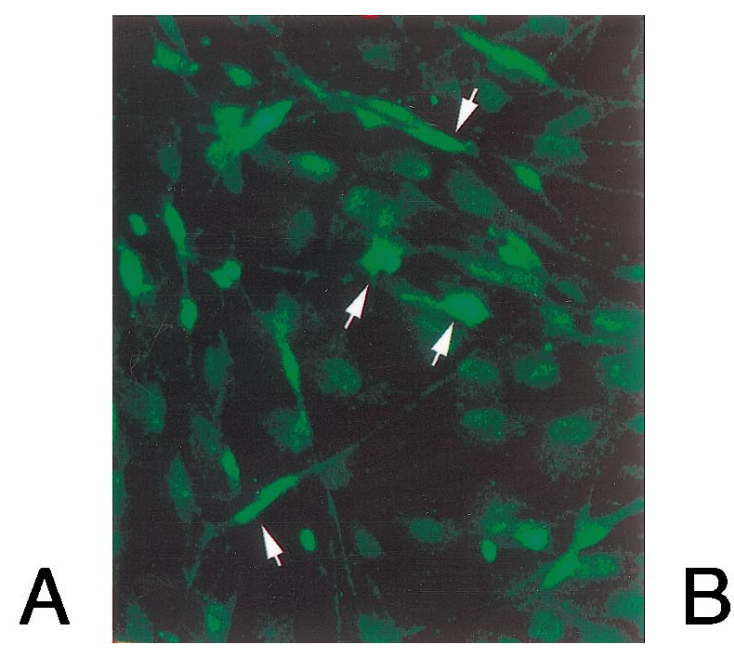

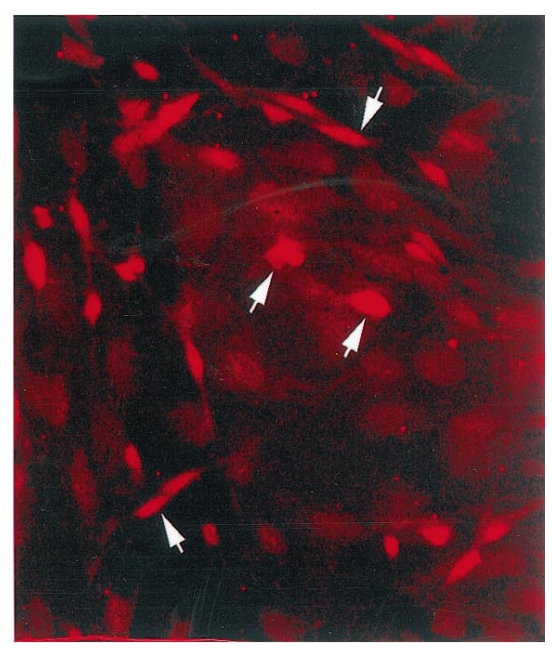

Figure 6. Colocalization of trkA and p75 immunoreactivity in leptomeningeal cells. Meningeal cells kept in culture for $5 \mathrm{~d}$ were fixed and incubated with antibodies against p75 and trkA. Fluorescent secondary antibodies were used to visualize $\mathrm{p} 75$ ( $A$, FITC, green) or trkA $(B, \mathrm{Cy} 3$, red $)$. There is a colocalization of p75 and trkA in most of the immunoreactive cells (arrows). 

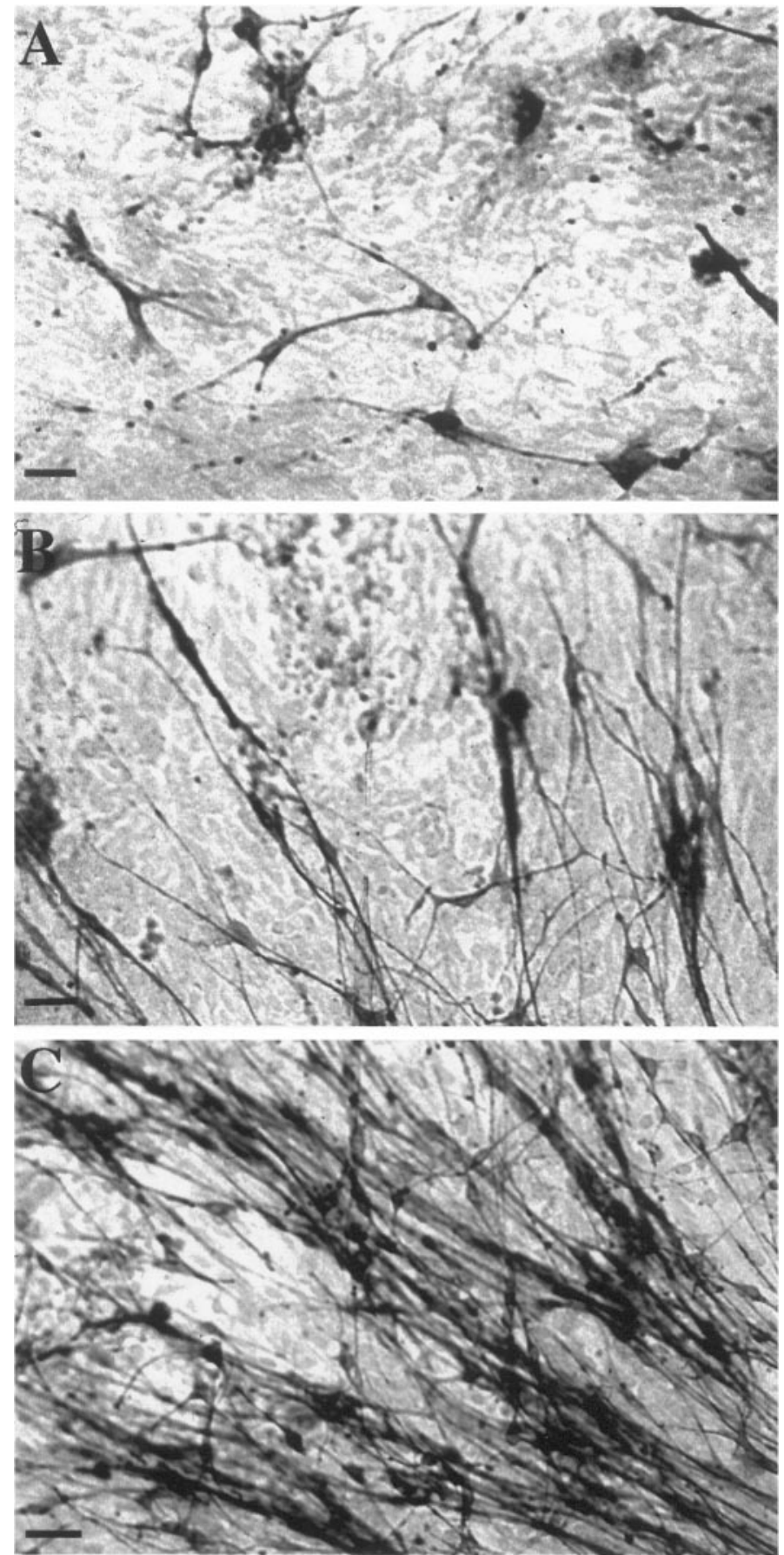

Figure 7. NGF induces process outgrowth in leptomeningeal cells. Leptomeningeal cells positive for $\mathrm{p} 75$ have short processes in vitro $(A)$. When $50 \mathrm{ng} / \mathrm{ml} \mathrm{NGF}$ is added to the cultures $(B, C)$ the cells extend long processes. Scale bars: $A, B, 25 \mu \mathrm{m} ; C, 50 \mu \mathrm{m}$.

\section{Leptomeningeal cells in the injured spinal cord express p75-LI and trkA-LI}

Leptomeningeal cells migrate into the CNS at penetrating injuries. We used a well established spinal cord injury model in the adult rat and cat to study leptomeningeal cells in the injured spinal cord. In this lesion model a longitudinal incision is made unilaterally in the lumbar ventral funiculus, resulting in proximal axotomy of spinal motoneurons. Many of the surviving motoneurons send axonal sprouts into the scar tissue that forms at the site
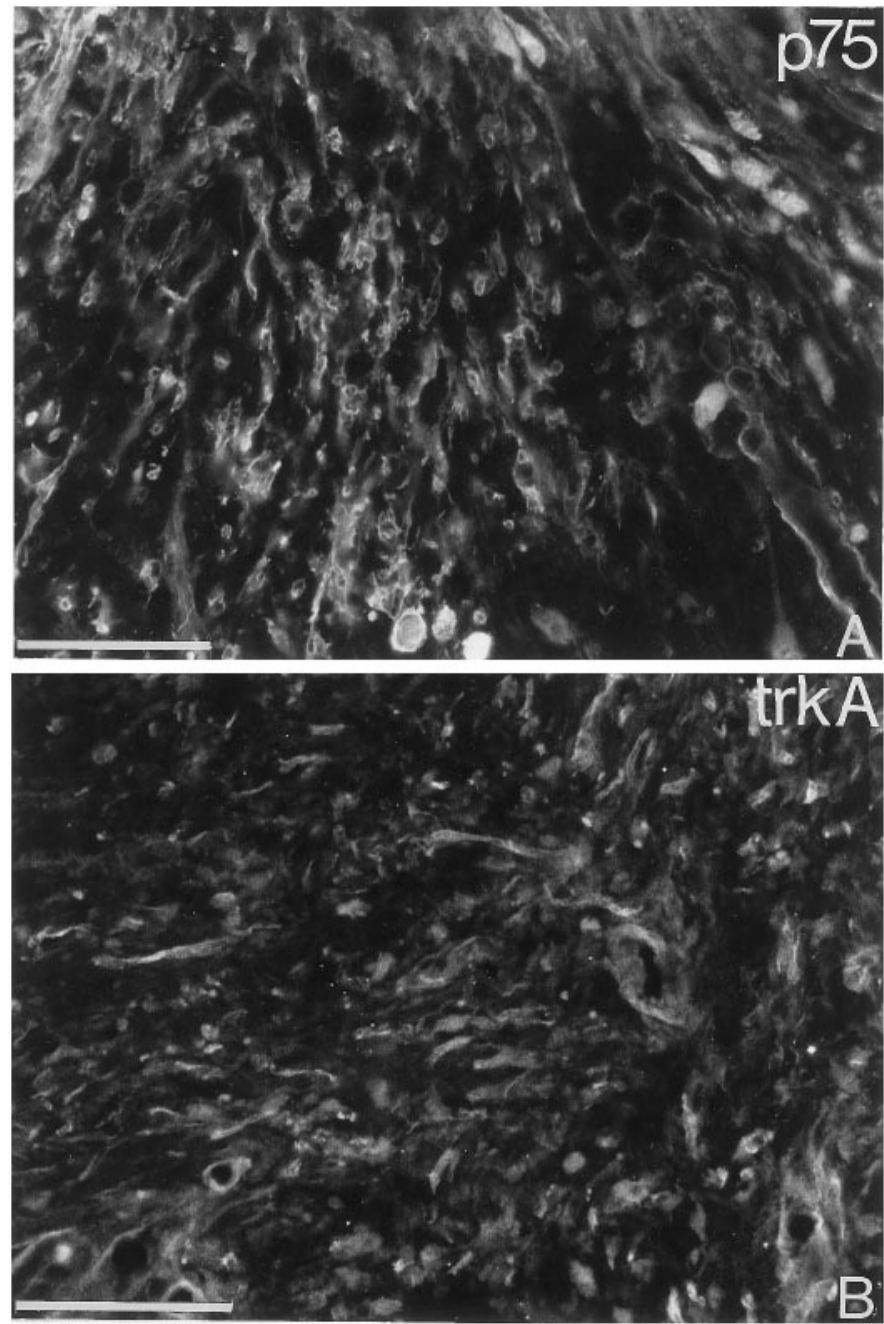

Figure 8. p75- and trkA-like immunoreactivity in the injured cat spinal cord. Immunofluorescence detection of p75-LI and trkA-LI in the scar tissue formed at a ventral funiculus lesion in adult cat. Scattered cells showing p75-LI $(A)$ and trkA-LI $(B)$ are seen in the scar tissue $10 \mathrm{~d}$ after the injury. Scale bars, $100 \mu \mathrm{m}$.

of the injury, and the axons often reinnervate the ventral root (Risling et al., 1983). Cells with long processes projecting through the scar showed p75-LI and trkA-LI (Figs. 8, 9). The scar tissue labeling was continuous with the pia mater (Fig. 9). The levels of p75-LI and trkA-LI in the cells in the scar tissue appeared similar to that in leptomeningeal cells in the pia mater. The time course for the invasion of cells showing trkA-LI and the extension of processes in these cells mimicked that described previously for p75-expressing leptomeningeal cells after injury (Risling et al., 1992). Thus, there was an increasing number of cells showing trkA-LI in the scar tissue from 4 to $10 \mathrm{~d}$ after the injury. During this time the staining pattern became more dense as more cells entered the scar tissue and the cells projected elaborate processes. The labeling pattern remained essentially the same at the later survival times. A similar pattern of p75-LI and trkA-LI was seen after an incision in the lateral funiculus in adult rats (data not shown). Immunoelectron microscopy demonstrated that the cells showing p75-LI and trkA-LI displayed ultrastructural characteristics of reactive leptomeningeal cells (Fig. 10). Doublelabeling was performed with antibodies to p75 and trkA to study whether both NGF receptors are coexpressed in the same lepto- 

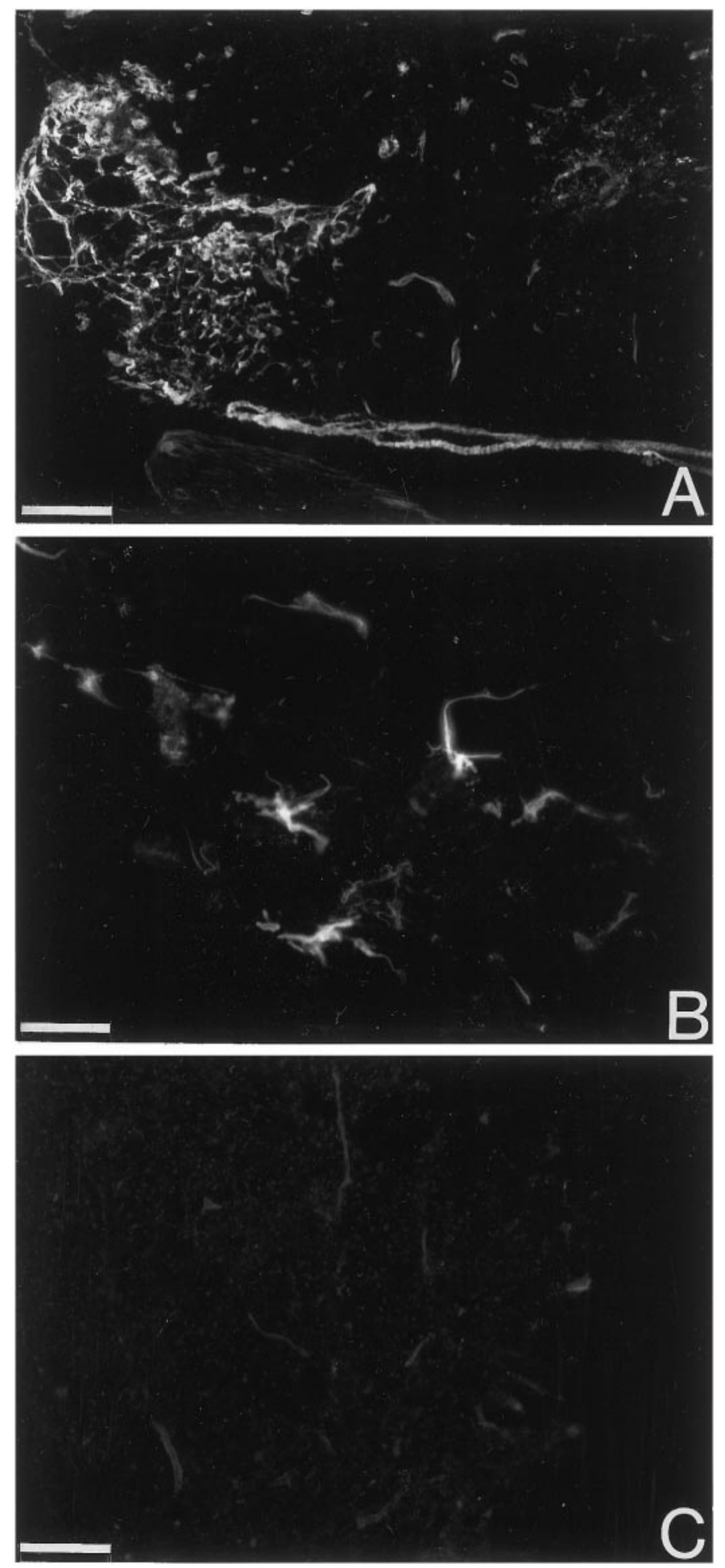

Figure 9. trkA-like immunoreactivity in the injured rat spinal cord. Immunofluorescence showing trkA-LI in the rat spinal cord $7 \mathrm{~d}$ after a ventral funiculus incision. The labeling in the scar tissue is continuous with the pia mater $(A)$. The cells in the scar have long slender processes $(B)$. All labeling is abolished in an adjacent section when the primary antiserum was preincubated with the peptide against which the antiserum was raised $(C)$. Note that the exposure is lighter in $C$ compared with $A$ and $B$. Scale bars: $A, 200 \mu \mathrm{m} ; B, 25 \mu \mathrm{m} ; C, 100 \mu \mathrm{m}$. meningeal cell. Visualization of trkA and p 75 was performed with silver-enhanced immunogold and peroxidase methodology, respectively, enabling ultrastructural examination of double-labeled cells. p75-LI and trkA-LI were coexpressed in most, if not all, leptomeningeal cells (Fig. 10B). Schwann cells, which often were seen on the surface of the spinal cord scar tissue, showed strong p75-LI at the cell membrane but no trkA-LI (Fig. 10C).

\section{DISCUSSION}

In this study we have characterized the expression of NGF receptors in leptomeningeal cells in the normal animal and after spinal cord injury and have analyzed the effects of NGF on these cells in vitro. Leptomeningeal cells express both known types of NGF receptors, p75 and trkA, and the presence of functional signal transducing NGF receptors is indicated by rapid tyrosine phosphorylation of trkA in response to NGF. NGF does not affect the proliferation of leptomeningeal cells, but induces process outgrowth in vitro. In animals that have undergone spinal cord injuries, p75-LI and trkA-LI leptomeningeal cells with long processes, morphologically resembling NGF-stimulated leptomeningeal cells in vitro, were scattered throughout the scar formed at the injury.

NGF induces differentiation of postmitotic trkA-expressing neurons (Levi-Montalcini, 1987). In contrast, NGF is mitogenic for some proliferating cells, such as adrenal chromaffin cells, neuronal stem cells, and fibroblasts ectopically expressing trkA (Lillien and Claude, 1985; Cattaneo and McKay, 1990; CordonCardo et al., 1991). Interestingly, we found that NGF was not mitogenic for proliferating leptomeningeal cells in vitro. Instead, NGF induced process outgrowth in these cells. It is not fully understood how tyrosine kinase receptor signaling in some situations can lead to proliferation and in other cases can lead to differentiation. The temporal dynamics of receptor activation may be important because sustained receptor activation over a longer period of time seems to be correlated with differentiation. Other studies suggest that activation of alternative signal transduction pathways may be more important for the outcome of receptor activation (for review, see Marshall, 1995; Kaplan and Miller, 1997). There is increasing evidence that p75 can facilitate signaling by trkA (Barker and Shooter, 1994; Hantzopoulos et al., 1994; Verdi et al., 1994; Maliartchouk and Saragovi, 1997; Rydén et al., 1997), although the mechanism is not known. Interestingly, MAH neuronal progenitor cells expressing p75 differentiate more rapidly in response to NGF compared with $\mathrm{MAH}$ cells lacking p75 (Verdi et al., 1994). Moreover, a pancreatic $\beta$ cell line (RINm5F), which expresses p75 and trkA, differentiates in response to NGF (Polak et al., 1993). Further characterization of NGF signal transduction pathways in leptomeningeal cells may provide information regarding the role of p75 in trkA signaling.

Leptomeningeal cells in the normal animal and in the injured spinal cord show strong p75-LI and trkA-LI and have long thin processes. This morphology resembles that of NGF-treated meningeal cells in vitro, indicating that NGF may induce this phenotype in vivo. We do not know whether leptomeningeal cells are exposed to NGF in the uninjured animal. However, we see a low degree of trkA phosphorylation in cultured leptomeningeal cells in the absence of exogenously added NGF (Fig. 4), indicating endogenous NGF production and autocrine stimulation in these cells. At CNS injuries, NGF synthesis by astrocytes is increased from very low or undetectable levels to rather high levels (Bakhit et al., 1991; Ishikawa et al., 1991; Lindholm et al., 1992b), which may affect meningeal cells invading the lesion site. The NGF 


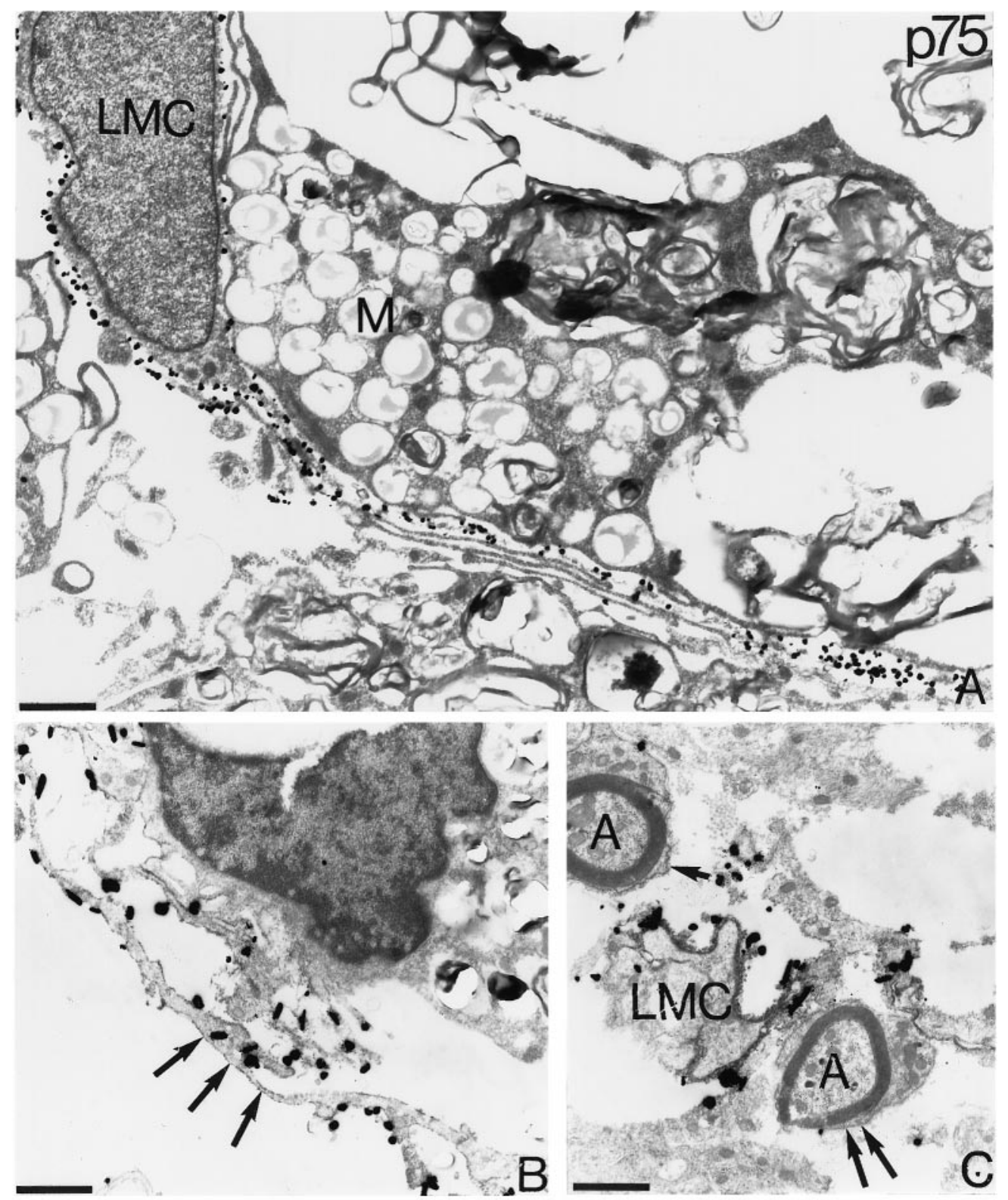

Figure 10. Coexpression of p75- and trkA-like immunoreactivity in leptomeningeal cells in the injured spinal cord. Silver-enhanced immunogold and ABC electron microscopy was used to localize p75-LI and trkA-LI in the spinal cord after ventral funiculus lesions in adult cats. In $A$ a leptomeningeal cell $(L M C)$ with a long process shows strong p75-LI as revealed by immunogold methodology. The adjacent macrophage $(M)$ is unlabeled $(A)$. In $B$ and $C$, p75-LI is visualized with $\mathrm{ABC}$, and trkA-LI is visualized with silver-enhanced immunogold methodology. Leptomeningeal cells with elongated processes coexpress p75-LI (dark peroxidase product by the cell membrane, arrows) and trkA-LI (B). In the superficial part of the scar tissue Schwann cells showing p75-LI (arrows) ensheath axons $(A)$. The Schwann cells do not show trkA-LI in contrast to leptomeningeal cells $(L M C)$, which show dense p75-LI and trkA-LI. All micrographs are from 3 weeks after the injury. Scale bars, $1 \mu \mathrm{m}$.

levels are highest during the first week after a lesion (Bakhit et al., 1991; Ishikawa et al., 1991; Lindholm et al., 1992b), corresponding to the time course for the invasion and process extension of leptomeningeal cells in the scar tissue. Interestingly, astrocyte conditioned medium can induce process formation by leptomeningeal cells but not by skin fibroblasts in vitro (Colombo et al., 1994). The present data suggest that NGF may be one astrocytederived factor that induces this morphological transformation of meningeal cells.

Glucocorticoids have been demonstrated to improve functional recovery to some extent after spinal cord injury in man (Bracken et al., 1990) and are now used in clinical practice. This effect may be somewhat unexpected because glucocorticoids downregulate NGF synthesis in astrocytes (Lindholm et al., 1992a) and thus may lead to less neurotrophic support for severed neurons. However, the data presented here suggests that NGF may participate in the formation of scar tissue at the site of injury, and decreased NGF levels at the lesion may modify the properties of leptomeningeal cells and affect CNS scarring and axonal regeneration.

\section{REFERENCES}

Bakhit C, Armanini M, Wong WLT, Bennet GL, Wrathall JR (1991) Increase in nerve growth factor-like immunoreactivity and decrease in choline acetyltransferase following contusive spinal cord injury. Brain Res 554:264-271. 
Barbacid M (1995) Neurotrophic factors and their receptors. Curr Opin Cell Biol 7:148-155.

Barker PA, Shooter EM (1994) Disruption of NGF binding to the low affinity neurotrophin receptor $\mathrm{p} 75^{\mathrm{LNTR}}$ reduces NGF binding to TrkA on PC12 cells. Neuron 13:203-215.

Beck KD, Lamballe F, Klein R, Barbacid M, Schauwecker PE, McNeill TH, Finch CE, Hefti F, Day JR (1993) Induction of noncatalytic trkB neurotrophin receptors during axonal sprouting in the adult hippocampus. J Neurosci 13:4001-4014.

Bracken MB, Shepard MJ, Collins WF, Holford TR, Young W, Baskin DS, Eisenberg HM, Flamm E, Leo-Summers L, Maroon J, Marshall LF, Perot PL, Piepmeier J, Sonntag VKH, Wagner FC, Wilberger JE, Winn HR (1990) A randomized, controlled trial of methylprednisolone or naloxone in the treatment of acute spinal-cord injury. New Engl J Med 322:1405-1411.

Cattaneo E, McKay R (1990) Proliferation and differentiation of neuronal stem cells regulated by nerve growth factor. Nature 347:762-765.

Chandler CE, Parsons LM, Hosang M, Shooter EM (1984) A monoclonal antibody modulates the interaction of nerve growth factor with PC 12 cells. J Biol Chem 259:6882-6889.

Chomczynski P, Sacchi N (1987) Single-step method of RNA isolation by acid guanidium thiocyanate-phenol-chloroform extraction. Anal Biochem 162:156-159.

Colombo JA, Napp MI, Puissant V (1994) Leptomeningeal and skin fibroblasts: two different cell types? Int J Dev Neurosci 12:57-61.

Cordon-Cardo C, Tapley P, Jing S, Nanduri V, O’Rourke E, Lamballe F, Kovary K, Klein R, Jones KR, Reichardt LF, Barbacid M (1991) The trk tyrosine protein kinase mediates the mitogenic properties of nerve growth factor and neurotrophin-3. Cell 66:173-183.

Crowley C, Spencer SD, Nishimura MC, Chen KS, Pitts-Meek S, Armanini MP, Ling LH, McMahon SB, Shelton DL, Levinson AD, Phillips HS (1994) Mice lacking nerve growth factor display perinatal loss of sensory and sympathetic neurons yet develop basal forebrain cholinergic neurons. Cell 76:1001-1011.

Davies AM, Lee K-F, Jaenisch R (1993) p75-deficient trigeminal sensory neurons have an altered response to NGF but not to other neurotrophins. Neuron 11:565-574.

Dechant G, Barde Y-A (1997) Signalling through the neurotrophin receptor p75 NTR. Curr Opin Neurobiol 7:413-418.

Ernfors P, Ibáñez CF, Ebendal T, Olson L, Persson H (1990) Molecular cloning and neurotrophic activities of a protein with structural similarities to nerve growth factor: developmental and topographical expression in the brain. Proc Natl Acad Sci USA 87:5454-5458.

Frisén J, Verge VMK, Cullheim S, Persson H, Fried K, Middlemas DS, Hunter T, Hökfelt T, Risling M (1992) Increased levels of trkB mRNA and trkB protein-like immunoreactivity in the injured rat and cat spinal cord. Proc Natl Acad Sci USA 89:11282-11286.

Frisén J, Verge VMK, Fried K, Risling M, Persson H, Trotter J, Hökfelt T, Lindholm D (1993) Characterization of glial trkB receptors: differential response to injury in the central and peripheral nervous system. Proc Natl Acad Sci USA 90:4971-4975.

Funakoshi H, Frisén J, Barbany G, Timmusk T, Zachrisson O, Verge VMK, Persson H (1993) Differential expression of mRNAs for neurotrophins and their receptors following axotomy of the sciatic nerve. J Cell Biol 123:455-466.

Götz R, Kolbeck R, Lottspreich F, Barde Y-A (1992) Production and characterization of recombinant mouse neurotrophin-3. Eur J Biochem 204:745-749.

Hallböök F, Ibáñez CF, Persson H (1991) Evolutionary studies of the nerve growth factor family reveal a novel member abundantly expressed in Xenopus ovary. Neuron 6:845-858.

Hantzopoulos PA, Suri C, Glass DJ, Goldfarb MP, Yancopoulos GD (1994) The low affinity NGF receptor, p75, can collaborate with each of the Trks to potentiate functional responses to neurotrophins. Neuron 13:187-201.

Ibáñez CF, Ebendal T, Barbany G, Murray-Rust J, Blundell TL, Persson H (1992) Disruption of the low affinity receptor-binding site in NGF allows neuronal survival and differentiation by binding to the trk gene product. Cell 69:329-341.

Ishikawa R, Nishikori K, Furukawa S (1991) Appearance of nerve growth factor and acidic fibroblast growth factor with different time courses in the cavity-lesioned cortex of the rat brain. Neurosci Lett 127:70-72.

Jing S, Tapley P, Barbacid M (1992) Nerve growth factor mediates signal transduction through trk homodimer receptors. Neuron 9:1067-1079.
Johnson D, Lanahan A, Buck CR, Sehgal A, Morgan C, Mercer E, Bothwell M, Chao M (1986) Expression and structure of the human NGF receptor. Cell 47:545-554.

Kaplan DR, Miller FD (1997) Signal transduction by the neurotrophin receptors. Curr Opin Cell Biol 9:213-221.

Kaplan DR, Hempstead BL, Martin-Zanca D, Chao MV, Parada LF (1991) The trk proto-oncogene product: a signal transducing receptor for nerve growth factor. Science 252:554-558.

Klein R, Conway D, Parada LF, Barbacid M (1990) The trkB tyrosine protein kinase gene codes for a second neurogenic receptor that lacks the catalytic kinase domain. Cell 61:647-656.

Klein R, Jing S, Nanduri V, O'Rourke E, Barbacid M (1991) The trk proto-oncogene encodes a receptor for nerve growth factor. Cell 65:189-197.

Lee K-F, Davies AM, Jaenisch R (1994) p75-deficient embryonic dorsal root sensory and neonatal sympathetic neurons display a decreased sensitivity to NGF. Development 120:1027-1033.

Levi-Montalcini R (1987) The nerve growth factor 35 years later. Science 237:1154-1162.

Lillien LE, Claude P (1985) Nerve growth factor is a mitogen for cultured chromaffin cells. Nature 317:632-634.

Lindholm D, Castrén E, Hengerer B, Zafra F, Berninger B, Thoenen H (1992a) Differential regulation of nerve growth factor (NGF) synthesis in neurons and astrocytes by glucocorticoid hormones. Eur J Neurosci 4:404-410.

Lindholm D, Castrén E, Kiefer R, Zafra F, Thoenen H (1992b) Transforming growth factor- $\beta 1$ in the rat brain: increase after injury and inhibition of astrocyte proliferation. J Cell Biol 117:395-400.

Maliartchouk S, Saragovi HU (1997) Optimal nerve growth factor trophic signals mediated by synergy of TrkA and p75 receptor-specific ligands. J Neurosci 17:6031-6037.

Marshall CJ (1995) Specificity of receptor tyrosine kinase signalling: transient versus sustained extracellular signal-regulated kinase activation. Cell 80:179-185.

Merlio J-P, Ernfors P, Jaber M, Persson H (1992) Molecular cloning of rat trkC and identification of cells expressing mRNAs for members of the trk family in the rat central nervous system. Neuroscience 51:513-532.

Middlemas DS, Lindberg RA, Hunter T (1991) trkB, a neural receptor protein-tyrosine kinase: evidence for a full-length and two truncated receptors. Mol Cell Biol 11:143-153.

Moran MF, Polakis P, McCormic F, Pawson T, Ellis C (1991) Proteintyrosine kinases regulate the phosphorylation, protein interactions, subcellular distribution, and activity of $\mathrm{p} 21^{\text {ras }}$ GTPase-activating protein. Mol Cell Biol 11:1804-1812.

Peters A, Palay SL, Webster HF (1976) The fine structure of the nervous system: the neurons and supporting cells. Philadelphia: Saunders.

Polak M, Scharfmann R, Seilheimer B, Eisenbarth G, Dressler D, Verma IM, Potter H (1993) Nerve growth factor induces neuron-like differentiation of an insulin-secreting beta cell line. Proc Natl Acad Sci USA 90:5781-5785.

Priestley JV (1984) Pre-embedding ultrastructural immunohistochemistry: immunoenzyme techniques. In: Immunolabelling for electron microscopy (Polak JM, Varndell IM, eds), pp 37-52. Amsterdam: Elsevier.

Radeke MJ, Misko TP, Hsu C, Herzenberg LA, Shooter EM (1987) Gene transfer and molecular cloning of the rat nerve growth factor receptor. Nature 325:593-596.

Risling M, Cullheim S, Hildebrand C (1983) Reinnervation of the ventral root L7 from ventral horn neurons following intramedullary axotomy in adult cats. Brain Res 280:15-23.

Risling M, Fried K, Lindå H, Cullheim S, Meier M (1992) Changes in nerve growth factor receptor-like immunoreactivity in the spinal cord after ventral funiculus lesion in adult cats. J Neurocytol 21:79-93.

Rodriguez-Tébar A, Dechant G, Barde Y-A (1990) Binding of brainderived neurotrophic factor to the nerve growth factor receptor. Neuron 4:488-492.

Rodriguez-Tébar A, Dechant G, Götz R, Barde Y-A (1992) Binding of neurotrophin-3 to its neuronal receptors and interactions with nerve growth factor and brain-derived neurotrophic factor. EMBO J 11:917-922.

Ross AHP, Grob M, Bothwell DE, Elder CS, Ernst N, Marano BFD, Ghrist CC, Slemp M, Herlyn B, Atkinson B, Koprowski H (1984) Characterization of nerve growth factor receptor in neural crest tu- 
mours using monoclonal antibodies. Proc Natl Acad Sci USA 81:6681-6685.

Rydén M, Hempstead B, Ibanez CF (1997) Differential modulation of neuron survival during development by nerve growth factor binding to the p75 neurotrophin receptor. J Biol Chem 272:16322-16328.

Smeyne RJ, Klein R, Schnapp A, Long LK, Bryant S, Lewin A, Lira SA, Barbacid M (1994) Severe sensory and sympathetic neuropathies in mice carrying a disrupted Trk/NGF receptor gene. Nature 368:246-249.

Sofroniew MV, Cooper JD, Svendsen CN, Crossman P, Ip NY, Lindsay RM, Zafra F, Lindholm D (1993) Atrophy but not death of adult septal cholinergic neurons after ablation of target capacity to produce mRNAs for NGF, BDNF, and NT-3. J Neurosci 13:5263-5276.

Squinto SP, Stitt T, Aldrich TH, Davis S, Bianco SM, Radziejewski C, Glass DJ, Masiakowski P, Furth ME, Valenzuela DM, DiStefano PS, Yancopoulos GD (1991) trkB encodes a functional receptor for brainderived neurotrophic factor and neurotrophin-3 but not nerve growth factor. Cell 65:885-893.
Thoenen H (1991) The changing scene of neurotrophic factors. Trends Neurosci 14:165-170.

Tsoulfas P, Soppet D, Escandon E, Tessarollo L, Mendoza-Ramirez J-L, Rosenthal A, Nikolics K, Parada LF (1993) The rat trkC locus encodes multiple neurogenic receptors that exhibit differential response to NT-3 in PC12 cells. Neuron 10:975-990.

Valenzuela DM, Maisonpierre PC, Glass DJ, Rojas E, Nuñez L, Kong Y, Gies DR, Stitt TN, Ip NY, Yancopoulos GD (1993) Alternative forms of rat trkC with different functional capabilities. Neuron 10:963-974.

Verdi JM, Birren SJ, Ibáñez CF, Persson H, Kaplan DR, Benedetti M, Chao MV, Anderson DJ (1994) p75 ${ }^{\text {LNGFR }}$ regulates Trk signal transduction and NGF-induced neuronal differentiation in MAH cells. Neuron 12:733-745.

Verge VMK, Merlio JP, Grondin J, Ernfors P, Persson H, Riopelle RJ, Hökfelt T, Richardson PM (1992) Colocalization of NGF binding sites, trk mRNA, and low-affinity NGF receptor mRNA in primary sensory neurons: responses to injury and infusion of NGF. J Neurosci 12:4011-4022. 